\title{
Cultivation of Oyster Mushroom (Pleurotus HK-37) On Solid Sisal Waste Fractions Supplemented With Cow Dung Manure
}

\author{
Prosper Raymond (Corresponding author) \\ Department of Molecular Biology and Biotechnology, College of Natural and Applied \\ Sciences, Uvumbuzi Road \\ University of Dar es Salaam, P.O. Box 35179, Dar es Salaam, Tanzania \\ Tel: 255-22-241-0223Ｅ-mail: promosha@yahoo.com
}

Anthony M. Mshandete

Department of Molecular Biology and Biotechnology

College of Natural and Applied Sciences, Uvumbuzi Road

University of Dar es Salaam, P.O. Box 35179, Dar es Salaam, Tanzania

\author{
Amelia K. Kivaisi \\ Department of Molecular Biology and Biotechnology \\ College of Natural and Applied Sciences, Uvumbuzi Road \\ University of Dar es Salaam, P.O. Box 35179, Dar es Salaam, Tanzania
}

Received: December 29, 2012 Accepted: January 10, 2013

doi:10.5296/jbls.v4i1.2975 URL: http://dx.doi.org/10.5296/jbls.v4i1.2975

\begin{abstract}
Solid sisal waste fractions which included composted sisal boles and sisal leaves decortication residues supplemented with cow dung manure at various rates used singly and/or in combination as substrates were investigated for cultivation of oyster mushroom (Pleurotus HK-37). The effect of the test sisal waste substrates and cow dung manure of
\end{abstract}


various supplementation rates were evaluated by mushroom yield, biological efficiency and mushroom size. Pinheads occurred in all substrates within 3 to 5 weeks of transfer of bags to the cropping room. The overall best results of mushroom production were obtained in a substrate combination of $50 \%$ sisal leaves $+50 \%$ sisal boles (based on $450 \mathrm{~g}$ wet weight substrate) supplemented by $30 \%$ cow dung manure with the mushroom yield of $184.64 \mathrm{~g}$ fresh mushrooms $/ \mathrm{kg}$ moist substrate weight and percentage biological efficiency (B.E) of about $63 \%$. Mushroom size of 6.10 was obtained in sisal boles substrate supplemented by $20 \%$ cow dung manure. Least yield of $26.73 \mathrm{~g}$ fresh mushrooms $/ \mathrm{kg}$ moist substrate weight and lowest B.E of $8.95 \%$ were obtained from non-supplemented substrate of sisal leaves alone. The study concluded that, supplementation using cow dung manure may play an important role on increasing the yield and productivity of Pleurotus HK-37 on solid sisal waste fractions under the conditions investigated.

Keywords: Solid sisal wastes, Pleurotus HK-37, Cow dung manure

\title{
List of abreviations:
}

\author{
BE - Biological efficiency \\ BY - Biological yield \\ MS - Mushroom size \\ MY - Mushroom yield \\ SB - Sisal boles \\ SL - Sisal leaf decortication residues \\ TS - Total solids \\ VS - Volatile solids
}

\section{Introduction}

Cultivation of Pleurotus species using lignocellulosic residues is the bioconversion process which offers the opportunity to utilize renewable bio-resources in the production of edible, protein-rich food (Sanchez et al. 2002). Various agricultural by-products are being used as substrates for the cultivation of oyster mushroom. In Tanzania, only $2 \%$ of the sisal plant is used while the remaining biomass after decortication is dumped near the factories, post harvest sisal boles (sisal stems) are either left on the field to rot, smashed or burnt thus causing serious environmental problems (Mshandete et al., 2008). Cultivation of mushroom on these solid residues can be viewed as an effective means to utilize bio-resource left behind and simultaneously as a sound environmental protection strategy. Furthermore, the use of these residues in bioprocesses may be one of the solutions to bioconversion of inedible biomass residues into nutritious protein rich food in the form of edible mushrooms (Mshandete and Cuff, 2008). 
Pleurotus species are found to be one of the most efficient lignocellulose solid state decomposing types of white rot fungi. Thus many agricultural and industrial wastes can be utilized for production of Pleurotus species as a substrate. Pleurotus have the ability to excrete hydrolyzing and oxidizing enzymes which have enabled them to flourish over a wide range of natural lignocellulosic waste materials (Pathmashini et al., 2008). Composted sisal decortications solid wastes were demonstrated to be a suitable substrate for cultivation of indigenous edible mushroom including Coprinus cinereus, Pleurotus flabellatus and Volvariella volvocea (Mshandete and Cuff, 2008). However, the suitability of composted sisal bole alone and/or a mixture of the composted bole with sisal leaf decortication residues for Pleurotus HK-37 mushroom cultivation is yet to be established.

To improve the productivity, nutritional value and shortening mushroom production periods several techniques, substrates, cultivation conditions and strains have been tested. Some studies show that supplementation with nitrogen source increases the biomass and mushroom's productivity (Curvetto et al., 2002; Shashirekha et al., 2005). However, in the literature no studies related to the effect of cow dung manure on mushroom yield, size and productivity of Pleurotus HK-37 grown on different solid sisal waste fractions either singly or in combinations have been reported.

Therefore, the present study was undertaken with a view to investigate the influence of cow dung manure as an additive to different solid sisal waste fractions either singly or in combination as substrates with a resultant effect on the biological efficiency, mushroom size and mushroom yield of Pleurotus HK-37.

\section{Material and Methods}

\subsection{Fungal Source and Maintenance of Culture}

Pleurotus HK-37 was obtained from strain bank of Department of Molecular Biology and Biotechnology, University of Dar es Salaam in Tanzania. This oyster mushroom strain originated from South Africa is among the oyster mushrooms grown in Tanzania (Mshandete, 2011). The fungi stock culture was maintained on malt extract agar (MEA). Cultures on plates were incubated at ambient temperature, which ranged from $25-30{ }^{\circ} \mathrm{C}$ for 5-7 days. Maintenance of pure mycelial cultures is a necessity for ultimate spawn preparation. Subcultures were made routinely every one-month.

\subsection{Spawn Preparation}

Spawn of this oyster mushroom were prepared with intact sorghum grains bought from Kariakoo market, Dar es Salaam. The grains were washed thoroughly, soaked in water for 15 minutes to allow them absorb moisture and thereafter parboiled for 10 minutes. After draining excess water, $1 \%(\mathrm{w} / \mathrm{w}) \mathrm{CaSO} 4$ and $2 \%(\mathrm{w} / \mathrm{w})$ of calcium carbonate $(\mathrm{CaCO} 3)$ were added and properly mixed into the grains to prevent sticking and adjusting $\mathrm{pH}$ before spreading them out on a clean plastic sheath. After air-drying for about $20 \mathrm{~min}, 150 \mathrm{~g}$ of the grains were packed in $330 \mathrm{ml}$ wide mouth bottles (Kioo Ltd, Dar es Salaam) and sterilized in an autoclave (Koninklijke AD Linden JR.BN-Zwijinderect, Holland) at $121{ }^{\circ} \mathrm{C}$ and 1 atm for 1 hour. Thereafter, each cooled bottle of sterilized grains was aseptically inoculated with three $1 \mathrm{~cm}^{2}$ 
pieces of mycelium malt extract agar (MEA) taken from 8 day-old cultures. Each inoculated bottle, with its cap closed, was shaken thoroughly by hand to distribute the mycelia to the grains. The mycelia inoculated grains were incubated in a ventilated incubator (Memmert $\mathrm{GmbH} \mathrm{KG}$, Schwabach FRG, Germany) set at $28{ }^{\circ} \mathrm{C}$ until the mycelia fully colonized the grains.

\subsection{Substrates Preparation and Characterization}

Sisal boles and fresh sisal decortications residues were collected from Kidugalo sisal decortications factory at Morogoro region, in Tanzania and were sun dried for 5 days. Fresh cow dung manure was obtained from local husbandry keeper at Ubungo - Kibangu, Dar es Salaam, Tanzania and was sun dried for five days and ground to fine powder using a laboratory blender (Snijders Scientific Tilburg, Holland, Waring Blender, Torington, CT, USA). The sisal boles were chopped into 3-4 cm lengths using a locally made manual chopper followed by grinding using forage cutter machine. The dried fibres from sisal boles were soaked in water for 2 hours to moisten them thoroughly and were subjected to a composting process for 14 days by covering with black polythene sheet. The composting method which manipulates the natural succession of microorganisms was used as previously described by Mshandete and Cuff (2008). The following modifications were made in the present investigation;

i. Fibres from sisal boles were used instead of sisal decortication residues.

ii. Dimensions of the pile were $0.9 \mathrm{~m}$ high $* 0.75 \mathrm{~m}$ wide $* 0.75 \mathrm{~m}$ long.

iii. Compost was turned every 3 days, starting on day 3 and ending on day 14 and on the same day the piles were dismantled.

Inner compost temperatures were measured as an indicator of microbial activity within the compost piles as described by Colak (2004). These measurements were made at 24 hour intervals. The qualitative characteristics of the finished compost which include color, softness and greasiness were observed at the end of the composting process as described by Mshandete and Cuff (2008). The finished sisal bole compost (abbreviated as SB in the rest of the paper) was used as a basal substrate for mushroom cultivation either alone or in combination with sisal leaf decortications residues (also referred as sisal leaves and abbreviated as SL in the rest of the paper). Before growing oyster mushrooms, these substrates were characterized as follows: Total solids (TS), volatile solids (VS) and the ash content of the substrate were determined by the oven-drying and ignition method, respectively according to standard methods APHA (1995). Total carbon was determined by the dry combustion method previously described by Allen (1989). The organic matter content was done by the dry combustion method as described by Lyimo et al., (2002). The total fibres were determined by ignition of previously oven-dried sample at $800{ }^{\circ} \mathrm{C}$ for 45 minutes. There after allowed to cool to room temperature before further ignition at $400{ }^{\circ} \mathrm{C}$ for 30 minutes (Mshadete et al., 2008).

\subsection{Mushroom Cultivation Experiments}

After characterization, the solid sisal waste fractions were then soaked in tap water for 2 hours to moisten. Excess water was allowed to drain until no water was dripping from the substrates. These substrates and dry cow dung manure were pasteurized at $70{ }^{\circ} \mathrm{C}$ for three hours 
(Koninklijke AD Linden JR BN-Zwijinderect, Holland), thereafter were left to cool before they were mixed. Four hundred fifty grams of each substrate formulation was packed into transparent polypropylene bags and based on the dry weight of the substrate, cow dung manure was supplemented at 10, 20 and $30 \%$. There were controls in each substrate in which no cow dung manure was added, labeled as $0 \%$ supplementation i.e. containing the substrate only. The spawn rate employed was $6 \%$ based on wet weight of the substrate (about $27 \mathrm{~g}$ per $450 \mathrm{~g}$ moist weight substrate). After inoculation, these bags were incubated on wooden shelves disinfected by $3 \%$ of hydrogen peroxide in a spawn running room as per Mshandete and Cuff (2008) recommendations. These experiments comprised of a split-split plot design, quadruple with solid sisal waste substrates as the main plot, varying cow dung manure supplementation levels as the sub-plot treatment.

\subsection{Spawn Running (mycelia development), Pinhead Initiation and Fruit Body Formation}

The spawning room was kept humid by pouring 10 litres tap water on the floor daily. Vegetative development was followed by direct observation of the inoculated substrates until the substrates were fully colonized by mycelia. Contaminants such as of the genus Trichoderma were also observed and noted but not quantified. The number of spawn run days for mycelia to colonize the substrate was recorded. During spawn running and fructification humidity and temperature was recorded using weather forecast clock (which simultaneously measures temperature and humidity) (Bright Weather Care, Scholer Quartz, Swiss). The conditions during spawn running in the room were $28 \pm 2{ }^{\circ} \mathrm{C}$ and relatively air humidity $78 \pm$ $2 \%$. After fully mycelia colonization the fruiting body formation was triggered by manipulating the environmental variables namely; moisture, air exchange, temperature and light as reported by Mshandete and Cuff (2008). Relative humidity and the temperature in the room were increased to $86 \pm 4 \%$ and temperature decreased to $26.5 \pm 0.05{ }^{\circ} \mathrm{C}$, respectively by pouring 25 litres of cold water and ice cubes per day on the floor and on the walls. When necessary, the moisture was maintained with the use of mist sprayers. Curtains on the windows were removed to allow ventilation and more light. These were done to initiate pinheads formation while at the same time lowering carbon dioxide concentration in the cropping room. Fruit primordials (pinhead) were allowed to develop to complete fruiting bodies and were picked. The oyster mushrooms were harvested when the in-rolled margins of the basidiomes began to flatten (Royse et al., 2004). The length of stipe and cap diameter of the harvested mushrooms was measured. Dates of each harvest were also recorded. Total number of flushes (flush number) produced per each bag was noted. The distribution of the yield per flush was tabulated to observe changes in yield over the course of multiple flushes. Duration of time from inoculation to final harvest was calculated. Seven aspects of crop yield were evaluated according to and Tisdale et al., (2006) as follows: (i) Mushroom size (MS). (ii) Biological efficiency (BE) (iii) Biological yield (BY) (iv) mushroom yield (MY) (v) flush number (vi) Crop period (sum of incubation and fruiting periods) (vii) Fresh weight.

BE values were calculated according to Stamets (2000), Royse et al., (2004). BE = [Weight of fresh mushrooms harvested (g) /dry substrate weight $(\mathrm{g})]$ x100 \%. On the other hand, MY values were calculated as previous reported by Morais et al., (2000). MY= [Weight of fresh mushrooms harvested ( $\mathrm{g}$ ) per fresh substrate weight]. The average MS was calculated as total 


\section{Macrothink}

fresh weight of mushrooms harvested divided by their total number of mushrooms. BY= [Weight of fresh mushrooms harvested (g) per dry substrate weight] and was expressed as $\mathrm{g}$ fresh mushrooms/kg dry substrate weight according to Amin et al., (2008). Average weight of individual mushrooms was determined as quotient of the total fresh weight mushrooms harvested by their total numbers according to Phillipoussis et al., (2002).

\subsection{Statistical Analysis}

All experiments were performed in quadruplets. The data on mushroom size, mushroom yield, and biological efficiency of Pleurotus HK 37, cultivated on these solid sisal wastes fractions supplemented with various amounts of cow dung manure were subjected to analyses of variance (one-way ANOVA) when significant differences were determined post test were made using Turkey multiple range test. The results are given as mean \pm SD.

\section{Results}

\subsection{Temperature Profile of the Sisal Boles Compost}

The temperature profile of the compost is shown in Figure 1. The highest temperatures were recorded at the second turning stage i.e. on the 4th and 5th days of composting. The raise in temperature is an indication of rapid and exothermic microbial activities within compost layers that play an important role in decomposition of carbohydrates to produce a better selective substrate for mushroom growing.

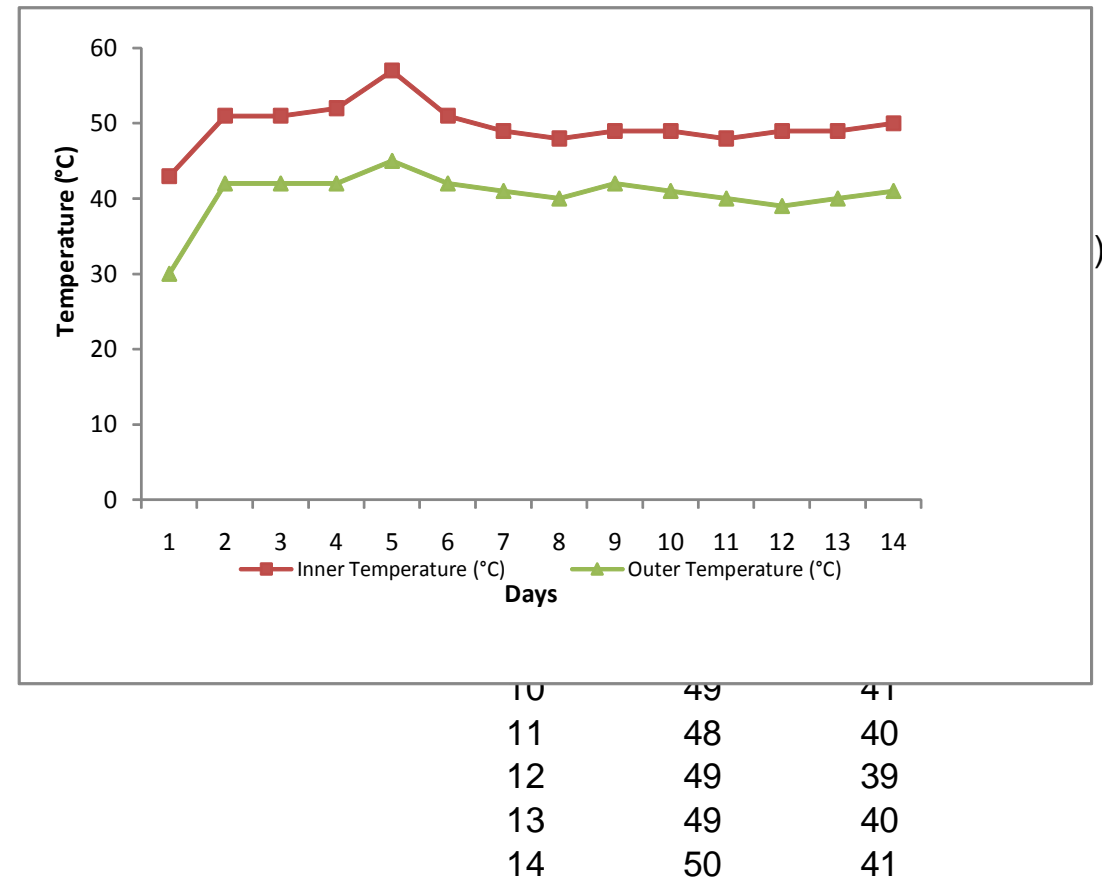

Figure 1. Temperature profile of $120 \mathrm{~kg}$ (dry matter) sisal boles compost pile during 14 days.

3.2 Chemical Composition of Solid Sisal Waste Fractions Used as Substrates for Oyster Mushroom Cultivation

The results regarding the major chemical components of dried solid sisal waste fractions for the cultivation of Oyster mushroom are indicated in Table 1. The moisture content ranged from 


\section{MInstitute Macrothink}

62.02 to $69.96 \%$. Regarding the total nitrogen content, the obtained data show that SL contained significantly higher amount being $1.68 \%$ followed by SL:SB (25:75) being $1.53 \%$ while SB recorded significantly lowest value being $1.14 \%$. All substrate formulations differed significantly for their ash contents. SL contained the highest ash value being $26.21 \%$ followed by SL:SB (25:75), $25.54 \%$ while SB recorded the lowest amount being $12.25 \%$.

Table 1. Proximate compositions of sisal waste fractions and supplement used as substrates for Pleurotus HK 37 mushroom cultivation (values are mean standard deviation (SD), n=3).

\begin{tabular}{|l|c|c|c|c|c|c|}
\hline Parameters & SL & $\begin{array}{c}\text { SL:SB } \\
(25: 75)\end{array}$ & $\begin{array}{c}\text { SL:SB } \\
(50: 50)\end{array}$ & $\begin{array}{c}\text { SL:SB } \\
(75: 25)\end{array}$ & $\begin{array}{c}\text { Supplement (cow } \\
\text { dung manure) }\end{array}$ \\
\hline $\begin{array}{l}\text { Moisture } \\
\text { content \% }\end{array}$ & $65.41 \pm 0.76$ & $62.02 \pm 0.78$ & $63.87 \pm 3.44$ & $66.49 \pm 2.13$ & $69.96 \pm 0.58$ & $75.33 \pm 0.89$ \\
\hline $\begin{array}{l}\text { Total solids (\% } \\
\text { fresh) }\end{array}$ & $34.59 \pm 0.76$ & $37.98 \pm 0.78$ & $36.13 \pm 3.44$ & $33.51 \pm 2.13$ & $30.04 \pm 0.58$ & $24.67 \pm 0.89$ \\
\hline $\begin{array}{l}\text { Volatile solids } \\
(\% \text { TS) }\end{array}$ & $73.79 \pm 0.76$ & $74.46 \pm 0.09$ & $81.92 \pm 2.26$ & $77.08 \pm 2.07$ & $87.75 \pm 0.55$ & $82.08 \pm 1.23$ \\
\hline $\begin{array}{l}\text { Ash content } \\
(\% \text { TS) }\end{array}$ & $26.21 \pm 0.76$ & $25.54 \pm 0.09$ & $18.08 \pm 2.26$ & $22.92 \pm 2.07$ & $12.25 \pm 0.55$ & $17.92 \pm 1.23$ \\
\hline $\begin{array}{l}\text { Total carbon (\% } \\
\text { TS) }\end{array}$ & $46.57 \pm 0.57$ & $49.67 \pm 0.24$ & $48.31 \pm 0.31$ & $47.72 \pm 0.08$ & $50.00 \pm 0.96$ & $16.02 \pm 0.48$ \\
\hline $\begin{array}{l}\text { Total organic } \\
\text { matter }(\% \text { TS) }\end{array}$ & $82.28 \pm 0.17$ & $87.09 \pm 0.54$ & $84.37 \pm 0.77$ & $82.49 \pm 0.59$ & $88.53 \pm 1.65$ & $28.87 \pm 0.78$ \\
\hline $\begin{array}{l}\text { Total Nitrogen } \\
(\% \text { TS) }\end{array}$ & $1.68 \pm 0.89$ & $1.53 \pm 0.45$ & $1.34 \pm 0.23$ & $1.26 \pm 0.18$ & $1.14 \pm 0.78$ & $4.72 \pm 1.37$ \\
\hline $\begin{array}{l}\text { Crude protein } \\
\text { (TNx6.25) }\end{array}$ & 10.5 & 9.56 & 8.38 & 7.88 & 7.13 & 29.5 \\
\hline Crude fiber & $14.21 \pm 0.68$ & $11.45 \pm 1.66$ & $13.39 \pm 0.58$ & $12.67 \pm 0.51$ & $11.90 \pm 2.26$ & nd \\
\hline
\end{tabular}

nd $=$ not determined

\subsection{Spawn Running (vegetative growth/mycelial development), Pinheads and Fruiting Bodies Formation}

The spawn running, pinheads formation and fruiting bodies formation are three important phases in the cultivation of mushroom; they require substrate, nutrients and proper growing conditions i.e. humidity and temperature. Table 2 shows that spawn running was completed within 2 weeks after inoculation depending on the sisal substrate formulations and cow dung manure supplementation levels. The Second stage of mycelial growth during mushroom cultivation is pinhead formation. The time taken for these pinheads to be formed after spawn running differed among sisal substrate formulations as shown in Table 2. A similar trend was observed for the third stage of fruiting body formation. The pinheads grew into mushrooms which were harvested $2-3$ days later.

Table 2. Days for completion of spawn running, pinheads and fruiting bodies formation

\begin{tabular}{|c|c|c|c|c|}
\hline $\begin{array}{c}\text { Substrate } \\
\text { formulation }\end{array}$ & $\begin{array}{c}\text { Supplement } \\
\text { level }\end{array}$ & $\begin{array}{c}\text { Days for } \\
\text { completion of } \\
\text { spawn running }\end{array}$ & $\begin{array}{c}\text { Days for pinheads } \\
\text { formation }\end{array}$ & $\begin{array}{c}\text { Days for fruiting } \\
\text { bodies formation }\end{array}$ \\
\hline & $0 \%$ & $13 \pm 1$ & $43 \pm 2$ & $46 \pm 3$ \\
\hline
\end{tabular}




\begin{tabular}{|c|c|c|c|c|}
\hline \multirow{4}{*}{ SB } & $10 \%$ & $12 \pm 1$ & $17 \pm 3$ & $20 \pm 2$ \\
\cline { 2 - 5 } & $20 \%$ & $12 \pm 1$ & $22 \pm 1$ & $27 \pm 3$ \\
\cline { 2 - 5 } & $30 \%$ & $12 \pm 2$ & $18 \pm 4$ & $22 \pm 3$ \\
\hline \multirow{4}{*}{ SB:SL (75:25) } & $0 \%$ & $13 \pm 1$ & $37 \pm 3$ & $41 \pm 2$ \\
\cline { 2 - 5 } & $10 \%$ & $13 \pm 1$ & $38 \pm 5$ & $41 \pm 1$ \\
\cline { 2 - 5 } & $20 \%$ & $12 \pm 1$ & $37 \pm 2$ & $41 \pm 4$ \\
\hline \multirow{4}{*}{ SB:SL (50:50) } & $30 \%$ & $12 \pm 1$ & $38 \pm 3$ & $42 \pm 3$ \\
\cline { 2 - 5 } & $0 \%$ & $13 \pm 1$ & $34 \pm 6$ & $38 \pm 3$ \\
\cline { 2 - 5 } & $10 \%$ & $12 \pm 1$ & $34 \pm 3$ & $37 \pm 2$ \\
\hline \multirow{3}{*}{ SB:SL (25:75) } & $20 \%$ & $12 \pm 1$ & $34 \pm 4$ & $38 \pm 5$ \\
\cline { 2 - 5 } & $30 \%$ & $12 \pm 1$ & $35 \pm 2$ & $48 \pm 4$ \\
\cline { 2 - 5 } & $10 \%$ & $13 \pm 1$ & $44 \pm 3$ & $46 \pm 2$ \\
\cline { 2 - 5 } & $20 \%$ & $13 \pm 1$ & $42 \pm 1$ & $44 \pm 5$ \\
\cline { 2 - 5 } & $30 \%$ & $12 \pm 1$ & $40 \pm 3$ & $45 \pm 6$ \\
\cline { 2 - 5 } & $10 \%$ & $12 \pm 1$ & $41 \pm 5$ & $46 \pm 3$ \\
\cline { 2 - 5 } & $20 \%$ & $14 \pm 2$ & $42 \pm 4$ & $42 \pm 2$ \\
\hline \multirow{3}{*}{ SL } & $30 \%$ & $13 \pm 1$ & $39 \pm 3$ & $42 \pm 4$ \\
\hline
\end{tabular}

3.4 Mushroom Yield and Yield Attributes of Oyster Mushroom Grown on Solid Sisal Wastes

Mushroom yield and yield attributes of P. HK-37 cultivated on different sisal waste formulations supplemented at various rates of cow dung manure are represented in Table 3. Mushroom yield was found in the range of 12.03 to $184.64 \mathrm{~g} / \mathrm{kg}$ wet substrate. The trend of mushroom yield was found to increase as supplement level increases i.e. yield response was linear in relation to increasing levels of nutrient.

The biological efficiency was worked out against the dry weight of substrate. Addition of different levels of supplements with sisal wastes increased biological efficiency. The best biological efficiency $(62.87 \%)$ was obtained by the addition of $30 \%$ cow dung manure with substrate formulation of SL:SB (50:50) which was significantly higher $(\mathrm{p}<0.005)$ as compared to all other treatments. The effect of different sisal waste formulations supplemented at various rates of cow dung manure on yield contributing characters such as stipe height and cap diameter was significant (Table 3 ). The stipe height on different substrates formulations ranged from 1.21 to $6.18 \mathrm{~cm}$. Cap diameter ranged from 1.85 to $6.57 \mathrm{~cm}$.

Table 3. Average number of mushroom fruit bodies, yield, biological efficiency and mushroom size of substrate formulations

\begin{tabular}{|c|c|c|c|c|c|c|c|}
\hline \multirow{3}{*}{ Substrate } & $\begin{array}{c}\text { Supplement } \\
\text { level }\end{array}$ & $\begin{array}{c}\text { No. of } \\
\text { fruit } \\
\text { bodies }\end{array}$ & $\begin{array}{c}\text { Cap } \\
\text { diameter } \\
(\mathrm{cm})\end{array}$ & $\begin{array}{c}\text { Stipe } \\
\text { height } \\
(\mathrm{cm})\end{array}$ & $\begin{array}{c}\text { Yield(g fresh } \\
\text { mushroom/Kg } \\
\text { wet substrate }\end{array}$ & $\begin{array}{c}\text { B.E } \\
(\%)\end{array}$ & $\begin{array}{c}\text { Mushroom } \\
\text { size }\end{array}$ \\
\hline \multirow{5}{*}{ SB } & $0 \%$ & 13 & $5.03 \pm 0.67$ & $3.12 \pm 0.33$ & 119.16 & 43.02 & 4.12 \\
\cline { 2 - 8 } & $10 \%$ & 18 & $5.41 \pm 0.44$ & $3.11 \pm 0.93$ & 122.97 & 44.39 & 3.07 \\
\cline { 2 - 8 } & $20 \%$ & 12 & $6.29 \pm 0.62$ & $2.90 \pm 0.35$ & 162.53 & 58.68 & 6.10 \\
\hline \multirow{3}{*}{ SL:SB (25:75) } & $30 \%$ & 22 & $4.67 \pm 0.48$ & $3.68 \pm 0.20$ & 171.12 & 61.78 & 3.50 \\
\cline { 2 - 8 } & $0 \%$ & 10 & $2.40 \pm 0.61$ & $2.24 \pm 0.38$ & 47.56 & 15.92 & 2.14 \\
\cline { 2 - 8 } & $20 \%$ & 10 & $2.48 \pm 0.48$ & $2.52 \pm 0.43$ & 49.11 & 16.44 & 2.21 \\
\hline
\end{tabular}




\begin{tabular}{|c|c|c|c|c|c|c|c|}
\hline & $30 \%$ & 27 & $1.85 \pm 0.24$ & $1.59 \pm 0.41$ & 100.67 & 33.7 & 1.68 \\
\hline \multirow{4}{*}{ SL:SB (50:50) } & $0 \%$ & 16 & $5.40 \pm 0.95$ & $4.65 \pm 1.42$ & 98.93 & 33.69 & 2.78 \\
\cline { 2 - 8 } & $10 \%$ & 24 & $6.57 \pm 1.67$ & $6.17 \pm 0.69$ & 146.92 & 50.02 & 2.75 \\
\cline { 2 - 8 } & $20 \%$ & 24 & $5.48 \pm 0.92$ & $5.68 \pm 0.65$ & 156.39 & 53.25 & 2.93 \\
\cline { 2 - 8 } & $30 \%$ & 23 & $5.66 \pm 0.23$ & $6.18 \pm 0.28$ & 184.64 & 62.87 & 3.61 \\
\cline { 2 - 8 } & $0 \%$ & 7 & $3.78 \pm 1.33$ & $2.95 \pm 1.43$ & 28.89 & 9.04 & 1.86 \\
\cline { 2 - 8 } & $10 \%$ & 14 & $2.92 \pm 0.23$ & $1.98 \pm 0.07$ & 90.44 & 28.32 & 2.91 \\
\cline { 2 - 8 } & $20 \%$ & 16 & $3.80 \pm 0.22$ & $3.44 \pm 0.44$ & 104.62 & 32.76 & 2.94 \\
\cline { 2 - 8 } & $30 \%$ & 23 & $3.16 \pm 0.10$ & $2.39 \pm 0.71$ & 123.24 & 38.59 & 2.41 \\
\cline { 2 - 8 } & $0 \%$ & 4 & $2.08 \pm 0.19$ & $1.44 \pm 0.39$ & 12.03 & 8.95 & 3.01 \\
\cline { 2 - 8 } & $10 \%$ & 9 & $2.32 \pm 0.03$ & $1.52 \pm 0.43$ & 23.78 & 17.69 & 2.64 \\
\hline \multirow{5}{*}{ SL } & $20 \%$ & 8 & $2.80 \pm 0.27$ & $1.21 \pm 0.97$ & 17.05 & 12.68 & 2.13 \\
\hline
\end{tabular}

\section{Discussion}

\subsection{Temperature Profile of the Sisal Boles Compost}

As it can be seen from Figure 1, the substrate outer layer did not reach $50{ }^{\circ} \mathrm{C}$ and stabilized between $30-45^{\circ} \mathrm{C}$ after 14 days incubation. The inner layer reached a maximum of $57{ }^{\circ} \mathrm{C}$ after 5 days of incubation and decreased to $49{ }^{\circ} \mathrm{C}$ where it stabilized for the rest of the process. Overtjins (1998) indicated that a treatment at $46{ }^{\circ} \mathrm{C}$ for one hour was enough to kill cecids; $50{ }^{\circ} \mathrm{C}$ during 10 minutes and four hours prevented the development of bacterial blotch and cobweb respectively. He also pointed that a few hours at $55^{\circ} \mathrm{C}$ or $60^{\circ} \mathrm{C}$ were necessary to kill other bacteria and fungi frequently encountered in white mushroom compost. According to the profile observed, and the need to avoid the growth of different wild organisms taken from the field in substrate (larvae and fly eggs, mites other insects, nematodes, various fungi and bacteria), this compost performed better when inner temperatures reached $50{ }^{\circ} \mathrm{C}$ and above thus allowing a time/temperature treatment providing enough heat to kill or inhibit contaminant microorganisms. Certainly, the action of temperature in the substrate after composting helped to inhibit most competitor organisms. The data are also in agreement with the highest inner compost temperature in the range of 52 to $82{ }^{\circ} \mathrm{C}$, which has been reported by other investigators depending on the compost formulations (Colak, 2004; Atikpo et al., 2008). The $\mathrm{pH}$ at the end of composting was slightly alkaline (7.2-7.8), allowing Pleurotus HK-37 spawn to develop in these substrate mixtures, while impeding the growth of other possible surviving fungi like Trichoderma spp. On the other hand, looking at the temperature profile it remains clear that substrate tumbling is important and necessary in order to aerate and provide a homogenous heat treatment to the substrate.

\subsection{Chemical Composition of Solid Sisal Waste Fractions Used as Substrates for Oyster Mushroom Cultivation}

The oyster mushrooms (Pleurotus HK-37) are known for their ability to degrade lignocellulosic residues from agricultural fields and forests and convert them into protein-rich biomass. The chemical constituents of sisal waste fractions are listed in (Table 1). The overall composition varied considerably among the fractions. The main reason can be due to 
differences in distribution of nutrients resources in plant fractions. Similar observation has also been reported for chemical composition of sisal waste fractions by Mshandete [13]. The low total crude fiber and high organic matter as well as total carbon indicated that these sisal wastes represent an abundant resource for bioconversion into value added bioproducts such as mushrooms. Although substrate composition analysis is important but does not always correlate with growth or yield of mushrooms it should be monitored to determine trends in substrate preparation for increased mushroom productivity.

\subsection{Spawn Running (mycelial development), Pinheads and Fruiting Bodies Formation}

The appreciable days to complete mycelium running of oyster mushroom on different substrates might be due to variations in their chemical composition and $\mathrm{C}: \mathrm{N}$ ratio as reported by Okhouya et al., (2005). Substrate is one of the important parameter in mushroom cultivation as mushrooms depend on substrates for nutrition to support mycelia growth and development into mushroom fruiting bodies. For the growth and penetration of the mycelium into basal substrates which ultimately influences fruiting of mushrooms, the structure and porosity levels (oxygen availability) of substrate are important factors to be considered (Philippoussis et al., 2002). The results on mycelial running were more or less similar to the findings of Shah et al., (2004). He reported that the spawn running took about 16-25 days after inoculation. Baysal et al., (2003) found the fastest spawn running (15.8 days) in waste paper as substrate. Royse et al., (2004), Tripathy et al., (2011); Mshandete et al., 2011) observed that the duration of different growth stages of cultivated mushrooms are affected by several factors which would include, but not limited to, type of substrates and supplements used, the type of species and/or the strain employed, spawn type and the rate of inocula/spawn applied, spawning method, spawning/cropping containers as well as on the prevailing mushroom growing conditions. Mycelia of Pleurotus species are well known to colonize various lignocellulosic materials due to their extensive enzyme systems capable of utilizing complex organic compounds, which occurs in organic matter residues (Tisdale et al., 2006; Mane et al., 2007). Thus a range of 12-14 days has been reported as time periods of spawn running for various Pleurotus species on lignocellulosic substrates (Stamets, 2000; Mane et al., 2007). Thus, the results from this study concur with the previous spawn running periods reported by others on Pleurotus species.

After completion of the spawn run, the bags were exposed to light. Tiny knots of mycelia were formed and differentiated into pinheads or primordia. The later lengthened and enlarged to form mature fruit. As depicted in (Table 2) the time taken for pinheads to appear after the spawn run period differed among the substrate formulations, and found to range between 3-7 weeks. Comparable results of Pleurotus species grown on different substrates has been reported by Royse et al., (2004); Baysal et al., (2003); Shah et al., (2004) and Mshandete, (2011). These pinheads grew into mushrooms, which were harvested 3-4 days later. The present findings are similar with those of Mshandete (2011) who reported on Pleurotus HK-37 and Pleurotus sapidus cultivated on cattail weed botanical fractions. The results in Table 2 also indicated that regardless of different sisal waste substrate formulations and supplement levels interval between flushes ranged between 5 to 9 days.

4.4 Mushroom Yield and Yield Attributes of Oyster Mushroom Grown on Solid Sisal Wastes 
The yield attributes and mushroom yield namely; mushroom fresh weight harvest, effective number of fruiting bodies, mushroom yield, biological efficiency, stipe and cap dimensions and mushroom size for Pleurotus HK-37 cultivated on different sisal waste substrate formulations with different supplement levels of cow dung manure are represented in Table 3.

The fruiting body is the edible part of mushroom. The results showed significant variability on the different sisal waste substrate formulations with different levels of cow dung manure supplement. The maximum number of fruiting bodies 24 were observed with an application of $10 \%$ and $20 \%$ of cow dung manure to SL:SB (50:50) substrate formulations while the minimum number 4 was observed in control SL substrate (no cow dung manure amendment). The number of fruiting bodies increased as the cow dung manure amendment percentage was increased. Shah et al., (2004) also cultivated oyster mushroom on different substrates and reported that average number of fruiting bodies harvested ranged from 7.22-22.11. Bhatti et al., (2007) observed 2.73-7.3 fruiting bodies per bunch while Kanhar et al., (2007) recorded 11-28.66 mushrooms per bag. The potential variation in the number of fruiting bodies could be due to different substrate combination in both physical and nutritional composition as well as microclimates (Amin et al., 2008).

A significant variation was observed in the different levels of cow dung manure supplementation to different sisal waste substrate formulations on mushroom yield and biological efficiency. The maximum mushroom yield (184.64 g) and biological efficiency (62.87 \%) was obtained with the $30 \%$ cow dung manure on SL:SB (50:50) substrate formulation. The lowest mushroom yield $(12.03 \mathrm{~g})$ and biological efficiency $(8.95 \%)$ was obtained on non-supplemented SL substrate. Generally, mushroom yield and biological efficiency results showed that were direct proportional with increasing supplement level regardless of the sisal waste substrate formulations employed. Similar trends of increasing yield with increasing supplement level to a certain optima have been reported on pad straw substrate supplemented with different supplements (Patil et al., 2011). The yields results (Table 3) demonstrated that different sisal waste formulations supported the growth of Pleurotus HK-37 differently. This furthermore, indicated that the mycelia of this oyster mushroom have different colonizing potentials for the substrates in which they are grown, which ultimately corresponded to the yield obtained.

The highest stipe length $(6.18 \mathrm{~cm})$ was observed from SL:SB (50:50) substrate after addition of $30 \%$ cow dung manure while the lowest $(1.21 \mathrm{~cm})$ was observed from SL substrate after addition of $20 \%$ supplement without any significant difference. Cap diameter of fruiting body ranged from 1.85 to $5.66 \mathrm{~cm}$ without any significant difference between treatments (Table 3). These results agreed with the findings of Samuel and Eugene (2012) who observed that pileus diameter ranged from 1.91 to $5.69 \mathrm{~cm}$ on different substrates.

The addition of $20 \%$ supplement level on SB substrate gave the relatively largest mean mushroom size $(6.10)$ and cap diameter $(6.29 \mathrm{~cm})$ respectively while longest stipe height $(6.18$ $\mathrm{cm}$ ) was obtained in SL:SB (50:50) substrate after addition of $30 \%$ supplement level. The variation in these parameters could be explained by the fact that the texture and substrate formulations as well as nutrients in cow dung manure possibly affected the composition of the 
final mushroom growth substrate and qualities such as water holding capacity and degree of aeration. Also, interactions between environmental factors and nutrients in mushroom growth substrate have been reported to play important role in inducing formation of the fruiting bodies which results in mushroom size variations (Reyes et al., 2009 and Kurtzman, 2010).

\section{Conclusion}

The results revealed that the organic ingredients in sisal boles composted within 14 days when mixed with sisal leaf decortication residues and supplementation by cow dung manure results in formation of a suitable substrate for successful cultivation of Pleurotus HK-37. Considering the mushroom yield and biological efficiencies overall best results were obtained on SL:SB (50:50) substrate formulation when supplemented by $30 \%$ cow dung manure. It can be concluded that solid sisal wastes are potential alternative substrates for production of oyster mushrooms. This process not only reduces waste disposal problems, but provides a means for their ecological utilization and could serve as an alternative source of income for sisal industry.

\section{Acknowledgement}

This study was sponsored by the World Bank project CIA 3.3 component "Industrial bioconversion of selected Tanzanian crops and residues into value added products using biotechnology" at the Department of Molecular Biology and Biotechnology (DMBB), College of Natural and Applied Science (CoNAS), University of Dar es Salaam (UDSM).

\section{References}

Allen, S. E. (1989). Chemical analysis of ecological materials. $2^{\text {nd }}(\mathrm{ed})$. Blackwell Scientific Publications, Oxford. p. 368.

American Public Health Association. (1995). Standard methods for examination of water and wastewater. $19^{\text {th }}$ Ed. American Public Health Association, Washington DC, USA.

Amin, R. S. M., Alam, N. Sarker, N. C. Hossain, K. \& Uddin, M. N. (2008). Influence of different amount of rice straw per packet and rate of inocula on the growth and yield of oyster mushroom (Pleurotus ostreatus). Bangladesh J. Mushroom, 2, 15-20.

Atikpo, M., Onokpise, O., Abazinge, M., Louime, C., Dzomeku, M., Boateng, L., \& Awumbilla, B. (2008). Sustainable mushroom production in Africa: A case study in Ghana. Afr. J. Biotechnol, 7, 249-253.

Baysal, E., Peker, H., Yalinkilic, M. K. \& Temiz, A. (2003). Cultivation of oyster mushroom on waste paper with some added supplementary materials. Bioresour. Technol. 89(1), 5-7. http://dx.doi.org/10.1016/S0960-8524(03)00028-2

Bhatti, M. I., Jiskani, M. M., Wagan, K. H. M., Pathan, A. \& Magsi, M. R. (2007). Growth, development and yield of oyster mushroom, Pleurotus ostreatus (JACQ.EX.FR.)Kummer as affected by different spawn rates. Pak. J. Bot. 39(7), 2685-2692.

Colak, M. (2004). Temperature profiles of Agaricus bisporous in compositing stages and effects of different composts formulas and casing materials on yield. Afr. J. Biotechnol. 3, 
456-462.

Curvetto, N. R., Figlas, D., Devalis, R., \& Delmastro S. (2002). Growth and productivity of different Pleurotus ostreatus strains on sunflower seed hulls supplemented with $\mathrm{N}-\mathrm{NH} 4+$ and/or $\quad \mathrm{Mn}(\mathrm{II}) . \quad$ Bioresource $\quad$ Technology, $84, \quad$ 171-176. http://dx.doi.org/10.1016/S0960-8524(02)00013-5

Kanhar, Q. D., Jiskani, M. M., Pathan, M. A. \& Nizamani, Z. A. (2007). Effect of urea on growth and yield of oyster mushroom, Pleurotus ostreatus (JACQ.EX.FR.) Kummer. Pak. J. Phytopathol. 19(2), 214-223.

Kurtzman Jr. R.H. (2010). Ventilation for mushroom cultivation: the importance of the needs of mushrooms and of the gas laws. Micol. Apl. Int., 22(2), 63-78.

Lyimo, T. J., Pol, A. \& Op den Camp, H. J. M. (2002). Methane emission, sulphide concentration and redox potential profiles in Mtoni mangrove sediment, Tanzania. Western Indian Ocean. J. Marine Science. 1, 71-80.

Mane, V. J., Patil, S. S., Syed, A. A. \& Baig, M. M. V. (2007). Bioconversion of low quality lignocellulosic agricultural wastes into edible protein Pleurotus sajor-caju (Fr.) Singer $J$. Zhejiang. Univ. Sci. (8), 745-751.

Mshandete, A. M. \& Cuff, J. (2008). Cultivation of three types of indigenous wild edible mushrooms: Coprinus Cinereus, Pleurotus flabellatus and Volvariella volvocea on composted sisal decortications residue in Tanzania. Afr. J. Biotech. 7(24), 4551-4562.

Mshandete,A. M. (2011a). Submerged and solid-state fermentation of the mycelium of Coprinus cinereus (Schaeff.) S.Gray s. lato mushroom on sisal bole wastes supplemented with human urine inTanzania. Inter. J. Research in Pure and Applied Microbiology. 1(3), 40-55.

Mshandete, A. M. (2011b). Cultivation of Pleurotus HK-37 and Pleurotus sapidus (oyster mushrooms) on cattail weed (Typha domingesis) substrate in Tanzania. Inter. J. Research. Biolo. Sciences. 1(3), 35-44.

Morais, M. H., Ramos, A. C., Matos, N., \& Santos Oliveira, E. J. (2000). Note, production of shiitake mushroom (Lentinus edodes) on ligninocellulosic residues. Food Sci. Technol. Int. 6, 123-128. http://dx.doi.org/10.1177/108201320000600206

Okhuoya, J. A., Akpaja, E. O. \& Abbot, O. (2005). Cultivation of Lentinus squarrosulus (Mont) Singer on sawdust of selected tropical tree species. Int. J. Mushroom Sci. (2), 41 - 46.

Overtjins A. (1998). The conventional Phase II in trays and shelves. Mush. J. 584, 15-21.

Pathmashini, L., Arulnandhy, V. \& Wijerathan, R. S. W. (2008), 'Efficancy of different spawn types on sawdust media', Tropical Agricultural research and Extension, 11

Patil, K. K. Kulkarni, R. V. \& Gupta, D.N. (2011). Enhancing Yield and Biological Efficiency (BE) in Oyster Mushroom by Supplementation. Academic J. Plant Sciences, 4(2), 41-44 


\section{Macrothink}

Philippoussis, A., Diamantopoulou,P., \& Zervakis, G. (2002) 'Monitoring of mycelial growth and fructification of Lentinula edodes on several lignocellulosic residues' Mushroom Biology and Mushroom Products, pp. 279-287, (eds. J.E. Sanchez, G. Huerts and E. Montiel) Universidad Autonoma del Estado de Morelos, Mexico, 2002.

Reyes, R. G., Lopez, L .L. M. A, Kumakura, K. Kalaw, S.P. \& Kikukawa, T. E. F. (2009). Coprinus comatus, a newly domesticated wild nutriceutical mushroom in the Philippines. J.Agric. Technol. 5(2), 299-316.

Shah, Z. A., Ashraf, M. \& Ishtiaq, M. C. (2004). Comparative study on cultivation and yield performance of oyster mushroom (Pleurotus ostreatus) on different substrates (Wheat straw, Leaves and Sawdust). Pakistan J. Nutrition. 3(3), 158-160. http://dx.doi.org/10.3923/pjn.2004.158.160

Shashirekha, M. N., Rajarathnam, S., \& Bano, Z. (2005). Effects of supplementing rice straw growth substrate with cotton seed on the analytical characteristics of the mushroom, Pleurotus florida (Block \& Tsao). Food Chemistry, 92, 255-259. http://dx.doi.org/10.1016/j.foodchem.2004.07.034

Stamets, P. (2000). Growing Gourmet and Medicinal Mushrooms, $3^{\text {rd }}$ edition. Ten Speed Press, Berkley, California. pp 1-574.

Samuel, A. A. \& Eugene, T. L. (2012). Growth performance and yield of oyster mushroom (Pleurotus Ostreatus) on different substrates composition in Buea South West Cameroon. Science J. Biochemistry. ISSN:2276-6294

Tisdale, T. E. Susan, C. \& Miyasaka-Hemmes, D.E. (2006). Cultivation of the oyster mushroom (Pleurotus ostreatus) on wood substrates in Hawaii. World. J. Microbiol. Biotechnol. (22) 201-206. http://dx.doi.org/10.1007/s11274-005-9020-5

\section{Copyright Disclaimer}

Copyright reserved by the author(s).

This article is an open-access article distributed under the terms and conditions of the Creative Commons Attribution license (http://creativecommons.org/licenses/by/3.0/). 